\title{
脳卒中標準データベースの有用性
}

小林 祥 泰

\section{Usefulness of Japanese Standard Stroke Database}

by

\section{Shotai Kobayashi, M.D., and Japan Standard Stroke Registry Study（JSSRS）Group from}

Department of Neurology, Hematology \& Rheumatology, Shimane University, School of Medicine

The Japan Standard Stroke Registry. Study (JSSRS) Group, is creating a permanent national acute stroke databank using an international stroke evaluation index. We analysed ultra acute thrombolytic therapy for ischemic stroke. Our data suggests that thrombolysis is effective in acute ischemic stroke in Japan. Concerning brain hemorrhage, our data shows that significantly better results were obtained from selectivery operated patients. The JSSRS system is basically working as a self computed database for acute stroke hospitals. Therefore, this database can help to confirm statistical data concerning patients and provide to make compaisions with other hospitals or Japanese data easily. It may also be a great help for preparing original data for informed consent and for information on hospital stroke therapy.

(Received July 22, 2004 ; accepted August 17, 2004)

Key words : stroke databank, outcome study, t-PA, Asian stroke research, Japan Standard Stroke Registry Study (JSSRS)

\section{Jpn J Neurosurg（Tokyo）14:3-9, 2005}

\section{脳卒中データバンク}

脳卒中データバンクのコンセプトは，1）診断基準統 一，2）重症度評価標準化，3）アウトカムスケール標 準化，4）各病院のデータベースとしての機能，5）日 本におけるデー夕集計が可能，6）諸外国や他施設との 比較が可能となることである.

著者らは，わが国における脳卒中の実態調査を継続的 に行うデータバンク構筑を目指して, 1999〜2002 年に厚 生科学研究事業による脳卒中急性期患者デー夕ベース構 築研究 (Japan Standard Stroke Registry Study; JSSRS) ${ }^{1}$ を 行い, 脳卒中病型㟝断〔National Institute of Neurological Disorders and Stroke（NINDS）の脳卒中III分類〕，重症度
評価〔National Institude of Neurological Stroke Scale (NIH SS）および Japan Stroke Scale (JSS) ]，アウトカムスケー ル〔modified Rankin Scale (mRS)]などを国際標準化し, 各病院のデータベースとして使用できるコンピュータ ベースの脳卒中急性期患者データベースシステムを構築 した。班研究終了後からは, 日本脳卒中協会データバン ク部門として登録事業を継続している。

現在の参加施設は，班研究終了時の 47 施設から 100 施設以上に増加し，日本の脳卒中データベースの標準と なりつつある。2002 年度までの解析結果は『脳卒中デー タバンク 2003』(中山書店) として 2003 年 3 月に出版 されている. また, 班研究成果およびその後の学会発表 などの要旨が, 脳卒中データバンクホームページ

島根大学医学部神経・血液・琹原病内科 $/ \bar{T} 693-8501$ 出雲市塩冶町 89-1 [連絡先：小林祥泰]

Address reprint requests to: Shotai Kobayashi, M.D., Department of Neurology, Hematology \& Rheumatology, Shimane University, School of Medicine 89-1 Enya-cho, Izumo-shi, Shimane 693-8501, Japan 
(http://cvddb.med.shimane-u.ac.jp/) に揭載されている ので, 睛味のあるうは参嗐していただきたい。2005年に は『脳苁中データバンク 2005』在出版予定である。また 今後, PDA版のソフト開発, 電子カルテとの連携システ ムの開発を進めていく予定で南る。

\section{脳卒中の病型別頻度および危険因子}

JSSRS2004 では，脳卒中全体（16,992 例）に上るる脳

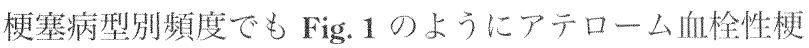
塞（血管一血管塞栓のアテローム血检性塞栓も含毛）が $24.3 \%$ とラクナ梗塞の $23.5 \%$ 孝回り，心原性脳基栓击 19\%とラクナ槙塞に近づいていた。アテローム血栓性梗 塞に括いても高而区が重要な四子であるので，畄卒中に 対する最大の危険因子であること変わりないが、ラク ナ梗塞が 40\%以上を占めていた以前と比較すると日本 人の脸卒中病型の分布が罢なってきでり, 上り欧米型 に近づいている印象がある。高血生性脳山值は $12.1 \%$ ， クモ膜下出血 (subarachnoid hemorrhage; SAH) は $5.5 \%$ であった。

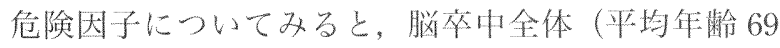
歳）に㧍ける高任压の頻度は63\%と，喫煙 $30 \%$ ，糖家
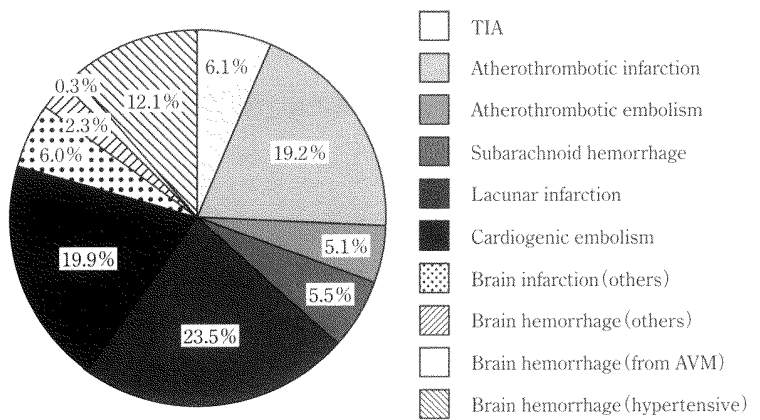

Fig. 1 Incidence of stroke by type (JSSRS2003, $n=16,992)^{4)}$
病 $23 \%$ ，高脂血症 $23 \%$ ，心病組動 $19 \%$, 飲酒整日 2 合 以上 $9 \%$, 脳卒中家族歴 $20 \%$ に比し最导頻度が高加 た2) $^{2}$.

\section{病型別にみた脳卒中の年代分布}

病型别によ゙の年代にピークがあるか老みてみると, Table 10ようにアデローム血栓憔梗塞，ラクナ梗举は 70 代がピークであるが，心原性脳塞检は7 70 〜 80 祡で ピークとなっており高榆者に多いこと走している。出 血性脳卒中のピークは脳梗举よりも若焦であった。今後 さらに高龄化が進めば，ますます心原性脸塞栓の頻度が 增加することが尔想され，琵介護となる後遗症增加に対 す当配慮が必琵となる。

\section{病型別にみた発症一来院時間}

JSSRS2001 の脳梗塞 5,405 例に㧍ける集䛨では，発症 3 時間以内の来院例は $38 \%$ で, 発症 6 時間以内を合わせ ると半数であった。これは全国 16,000 例の脳梗举を集貄

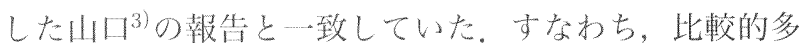
くの例が租检溶解療法の適応となる 3 時間以内に来院 していることがうかがかれ，近い将来，わが国で組替 光組織プラスミノゲンアクチバーター ( れた際には，brain attack キャンペーンなどにより超急性

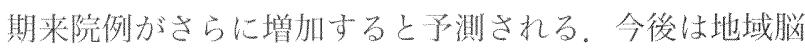
卒中拠点病院の上うに, 程度センタ一化して，適必例を多く集め效率よく治療す る力籍老考元ていく必要がある。去た，発症一来院時間 に嚾かながら地域差もあり，関東地区では比較的時間が かかっている傾问が愍められた。

Table 1 Incidence (\%) of stroke subtype according to age (JSSRS2002, $\mathrm{n}=16,992$ )

\begin{tabular}{lccccc}
\hline & $<50$ years & $50-59$ years & $60-69$ years & $70-79$ years & 80 years $\leqq$ \\
\hline TIA & 6.994 & 15.179 & 27.976 & 31.994 & 17.857 \\
Atherothrombotic infarction & 3.389 & 13.202 & 26.909 & 33.789 & 22.711 \\
Atherothrombotic embolism & 2.467 & 8.729 & 25.996 & 39.089 & 23.719 \\
Subarachnoid hemorrhage & 18.341 & 25.359 & 23.604 & 21.531 & 11.164 \\
Lacunar infarction & 3.670 & 17.732 & 28.701 & 32.041 & 17.856 \\
Cardiogenic embolism & 3.231 & 8.300 & 21.223 & 36.531 & 30.716 \\
Brain infarction (others) & 17.091 & 13.636 & 23.091 & 28.909 & 17.273 \\
Brain hemorrhage (others) & 13.566 & 14.341 & 20.155 & 31.395 & 20.543 \\
Brain hemorrhage (from AVM) & 54.286 & 22.857 & 8.571 & 14.286 & 0.000 \\
Brain hemorrhage (hypertensive) & 9.005 & 22.396 & 29.287 & 25.607 & 13.704 \\
\hline Total & 6.361 & 15.164 & 25.907 & 31.931 & 20.673
\end{tabular}




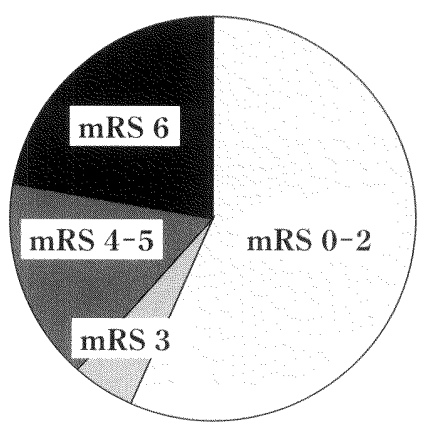

Subarachnoid hemorrhage

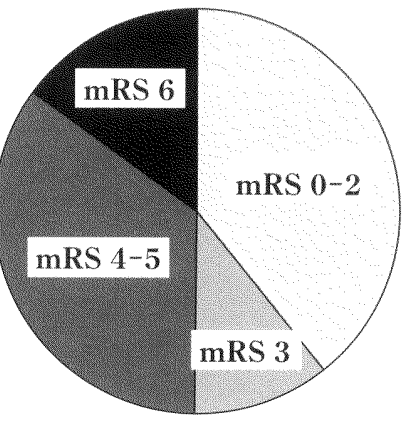

Hypertensive brain hemorrhage

$$
n=458
$$

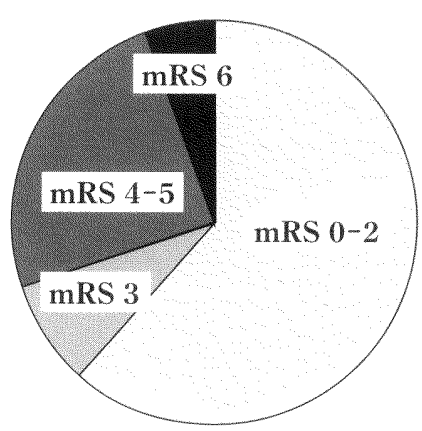

Ischemic stroke

$n=5,765$

Fig. 2 Prognosis at hospital discharge for stroke by type (modified Rankin scale) $($ JSSRS 2001)

\section{急性期脳卒中の病型別退院時予後}

JSSRSによるmRSでタた病型别退院時予後老Fig. 2 にホすす、SAHでは死し率は高いが寢たきりは少なく、比 較的軽症で，手術施行䕌例は予後が良好なこと走して いる。当然のことながら, 入院時の Hunt \& Kosnikの

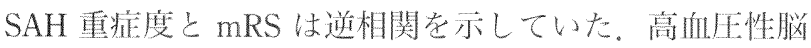
H血は旺に比べて激減したとはいえ, SAHについで死し 率が高く、葠たきりになる率も高い予後不良の病型であ る。脳梗塞では死亡辩は低いが㯖たきりになる頻度はか なり高い。その大半は高龄者の心原性脳塞栓によるもの である。心原性脳塞栓では誛たきり技よび死しが30\%に 及び，子後不良（mRS：5-6）な脳梗塞の寒に51\%を心 原性脳塞栓が占めていた2．

心房細動があれば当然抗凝固憭法の適店となるが，抗 凝固・血小板療法の有無で办た高血性脳出血の退院帱

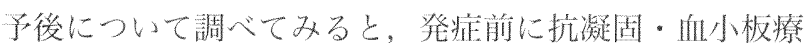
法施行群で有意に死亡率が高いことが判明しだ，以前 から，抗血小板蒋服用例では，血腫が進行性に抾大する 例があるという印象老持っていたが，今回の集計でをの ことが裏づけられた。最近ではMRI T2*鼣像法が普及 し，潜在性小出血も搒断できるようになってきたので， 潜在性小出卹が多発するような其型的なラクナ倳塞で は，抗血小板楽上りも高伹压の管理を十分に行うことが 重要て好。

\section{超急性期血栓溶解療法の実施頻度と 退院時予後}

Brain attack とは発症 3 時間以内の可及的速やかな晌

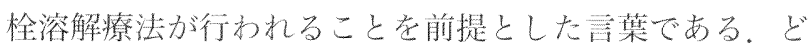

んなに早く来院してもこの治療なくしては治療效果は 運任せである。米国では血栓浴解療法の䁈蒙キャンペー ン索大々的に行い, 最近の米国の脳公中七ン夕一共同研 究の 6,000 例の集計では, t-PA 投与流は適応例全体の $4.6 \%$ でるが, 発症 1 時間以内脳梗兴入院例では $58.6 \%$ にも達していると報告されている5゙。わが国ではいまた 脳梗塞に对するt-PAの保鮧適笖は認めら机ていない が, JSSRSの集䚵によるとtーPAや大量り口キナーゼ

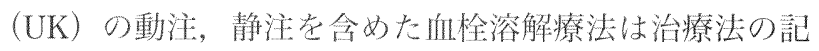
載の女る脳棰塞 5,874 例中 226 例 $(3.8 \%$ ) に施行されて

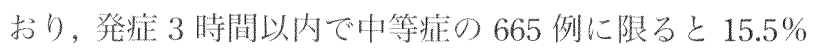
の例で施行されていだ．静注 t一PAの效果が非常に大き いのはやはり発症 1 眭間以内でありフ, わが国において も救急隊と連携してこの超急性期細梗塞例を增やす努力 が必要である。JSSRSによる血栓浴解燎法の retrospective 解析でも, Fig. 30 上うに mRS 0-1 と社全復师可能 な例が $32 \%$ と刘照群の $20 \%$ に比し, 高染であっだ). 刘 照群において発㨁 3 力月後の子後についても調查した が, mRS 0-1は21\%とほぼ同様の結果であった8，米国

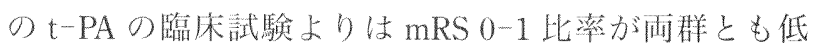
めであるが、米国の試験と異なり NIHSS 6 6-29の中 等一直症例を選把していることが影響しているものと思 小れる。

JSSRS2003による集計ではt-PA 静注が 99 例に行わ れていたので, 血栓溶解療法老内容别に分けて, 笑施さ れた全例について子後を検討して双た。Fig.4 に示す上 うにt-PA 静注投与群で退院時 mRS 0-1 が 37\%と最も 商く、また死亡率も最专低かった。この結果はt一PAの オープン試験の成績ときわめて類似した結果であり, 十 分適底を考慮したうえで健用されるt-PA静注投与は， 比較的安定した效果と定全性を示すことを禾唆するもの 


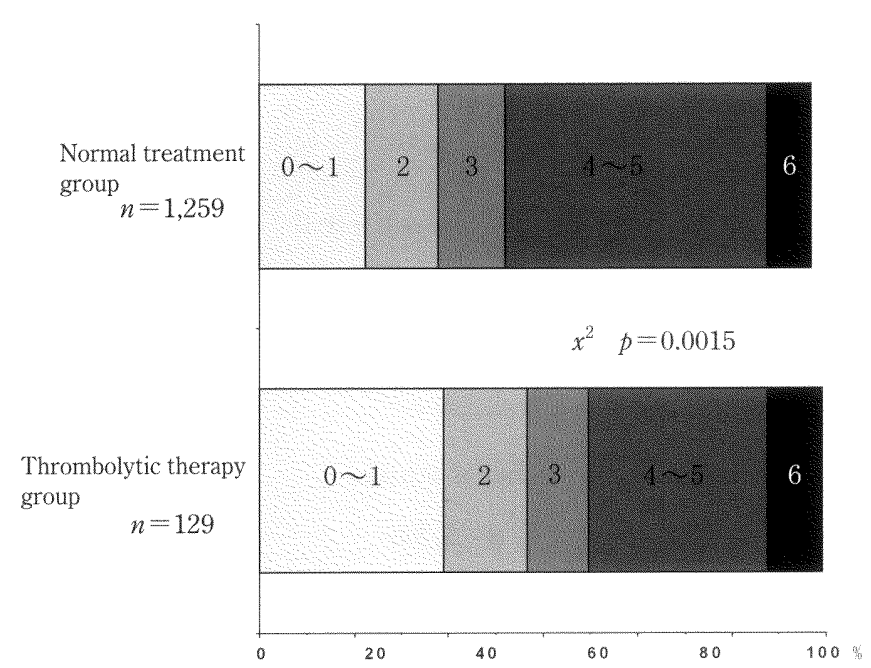

Fig. 3 The effects of thrombolytic therapy (tPA intravenous and intraarterial, and UK intraarterial and mega dose intravenous), and in brain infarction acute stage patients (Severity at admission : NIHSS 6-29) were compared with those of a conventional treatment group of the same severity. (JSSRS 2001) ${ }^{4)}$

\section{と思われる。}

病型別実施頻度は Fig. 5 で示すように心惊性脳塞栓で 約 $8 \%$ と最も高く，アテローム血栓性梗塞でも $2 \%$ 程度 に施行されていることがわかる。

入院時, 重症度别に血栓溶解療法の子後をみると, Fig. 6に示したようにNIHSS 5-9 で mRS 0-1 頻度が 60\%近 くであるのみならず, NIHSS15-20の重症例においても 著效例が $25 \%$ と多く, 非施行群との差が拡大している己 とがわかる。

\section{脳卒中標準データベースの利点}

ガイドラインとデータベースの関係については，前者 は EBM に基づいた最適な治療法を提示するのが目的で あるが，必ずしも結果に出ない。一方，後者はアウトカ ムアプローチで治療結果を提示するが, 結果が瑟くても 改善策を提示できないという相互補完的なものであると されている。すなわち,ガイドラインの检証にデータベー スが必要となることを示唆している。

脳卒中標準データベースの利点としては，各施設にお ける独立したデータベースとして標準化データが蓄積さ れ，臨床統棓 (自己評価)，臨床研究，情報開示に有用で あること，共通部分を電子データで全国集尌ずることに より日本の脳卒中㟝療の実態を迅速に把握可能であるこ と，学会などの管理による準公的集䚵解析システムによ

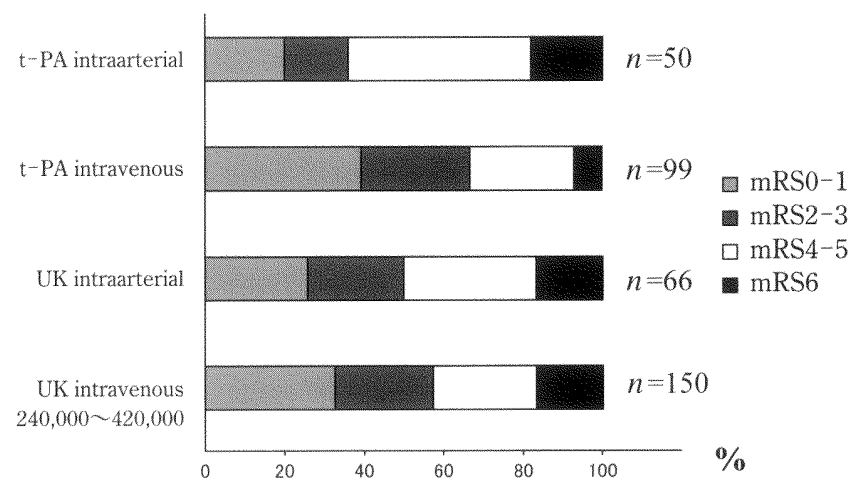

Fig. 4 Prognosis at hospital discharge for 365 patients who underwent thrombolytic therapy (modified Rankin scale)

(TIA, brain infarction: $n=11,793$, within 1 week of onset, JSSRS 2003)

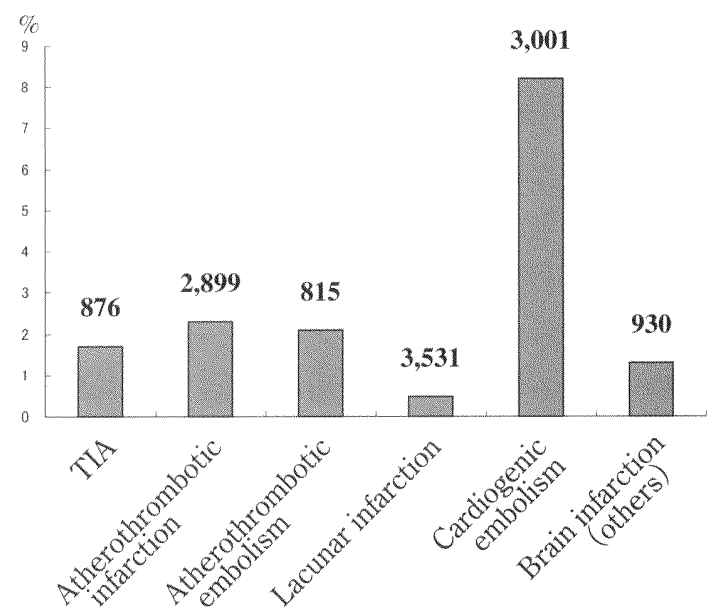

Fig. 5 Incidence of thrombolytic therapy according to subtype of brain infarction (admitted within 1 week) $n=12,052 \quad$ (JSSRS 2003)

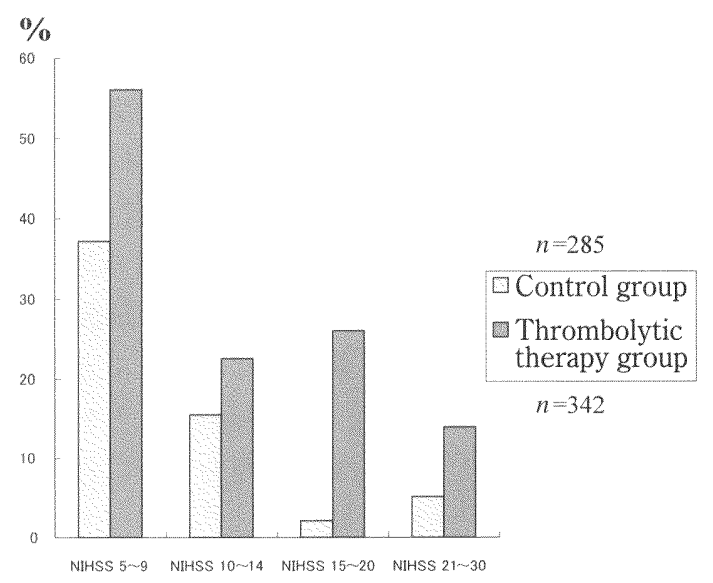

Fig. 6 Effects of thrombolytic therapy according to severity at admission (mRS 0-1 ratio)

Thrombolytic therapy group prognosis at discharge; Control group prognosis at 3 months. Targets were subjects hospitalized within 3 hours of onset who were graded NIHSS 5-30 at admission (JSSRS 2003) 
Table 2 Comparison of onset patterns of brain infarction and brain infarction type in Shenyang (China) investigated by stroke standard database

\begin{tabular}{lcccc}
\hline & Pattern of onset and subtype of brain infarction in Shenyang (China) and Japan & \\
\hline & Sudden complete & Acute onset & Onset during sleep & Stepwise progression \\
The First Hospital of Shenyang & $2.5 \%$ & $49.6 \%$ & $12.8 \%$ & $35.1 \%$ \\
China Medical University & $2.4 \%$ & $50.6 \%$ & $3.6 \%$ & $41.8 \%$ \\
Japan & $34.2 \%$ & $40.0 \%$ & $10.3 \%$ & $13.5 \%$ \\
\hline \multicolumn{5}{c}{ Brain infarction types (\%) in Shenyang (China) and Japan } \\
\hline TIA & The First Hospital of Shenyang & China Medical University & Japan \\
Atherothrombotic infarction & 2.0 & 4.9 & 8.7 \\
Lacunar infarction & 74.9 & 80.3 & 28.7 \\
Cardiogenic embolism & 18.5 & 12.1 & 28.0 \\
Brain infarction (others) & 1.1 & 2.6 & 0 \\
\hline
\end{tabular}

る指定病院群でのガイドライン実証研究や，大規模共同 研究への応用が可能であること，臨床研修必修化に伴う 研修医教育への活用，アウトカムアプローチによる医療 の質の確保に貢献する可能性があること, 将来的に共通 の文化を持つアジアで，大規模共同研究を行う際にも役 立つ可能性などが挙げられる。

\section{中国の瀋陽の病院との共同研究による 日中比較}

著者らは，人口 600 万人の潘陽第一病院（脳専門病院 で神経内科，脳神経外科を重点配置）と，瀋陽にある中 国医科大学神経内科 (以下, 中国医大) と同じデータベー スを用いて脳卒中登録の共同研究を行っているので,

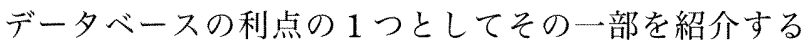
$\left(\right.$ Table 2) ${ }^{9)}$.

中国東北地方では，高血圧性脳出血が日本の 30 年前 に匹敵するほど多く，脳神経外科ではもつぱら脳出血の 手術を行っている。しかし, 30 年前の日本とは違ってゴ マ油を多用するためか, アテローム血栓性梗塞の頻度が 高いという結果であった。これに関しては診断技術の問 題もある可能性を考え, MRI のある中国医大にも依頼し て調査したが，やはり結果は同じであった，脳梗塞で最 も大きな違いは心原性脳塞栓が潘陽第一病院で $1.1 \%$, 中国医大でも $2.6 \%$ と日本の $26.7 \%$ に比して圧倒的に少 ないことであった。これについて危険因子を検討してみ ると, 心房細動の頻度が約 $1 / 10$ と少なく, 突発完成型 発症の頻度が潘陽第一病院 $2.5 \%$ と, 日本の $34.2 \%$ に比 し明らかに少なかった。これらの事実は，瀋陽では心原 性脳塞栓がきわめて少ないことを裏づけるものと思われ る. 実際に瀋陽第一病院で病棟を回っても, 重症例が少 ない印象を受けた。これは瀋陽の脳卒中患者の平均年齢
が 6 歳程度若いことが関係しているかもしれない.心房 細動は加秢と共に増加することはよく知られており，脳 卒中データバンクでも同様の結果を得ている.

\section{海外での脳卒中データバンクの動向}

ドイツでは t-PA 治療の管理のため，200脳卒中セン ターが共同でデータバンクを構築し, German Stroke data bank として中央での 3 力月执よび 1 年後の, 電話に よる予後追跡調査を実施している。このデータバンクで 6,234 例の脳梗塞を解析したところ, そのうち $4 \%$ に一 $\mathrm{PA}$ 治療が行われていたが脳出血は $8.8 \%$ と少なく，3力 月後の mRS 0-1 は 35\%であった。このようなシステム を用いれば，短期間に精度の高い phaselVの臨床試験に 相当する結果を得ることができると述べている ${ }^{10)}$ 。この システムはドイツ厚生省がサポートする水平型データバ ンクで, 主要な脳卒中センターの大半が参加した臨床的 脳卒中ネットワークとして, 将来的に遺伝子研究, 画像, Stroke Unit などを加味した permanent infrastructure を 目指すとしている。

カナダでも同様に，厚生省その他による基金を基に大 規模な脳卒中ネットワークシステムを構築している。こ のシステムでは, 発症 2 週間以内の入院例を対象に 6 力 月後の予後を中央で調査し集計している。わが国と異な り nurse coordinator が同意をとり管理し，Webで入力し 電送する仕組みで，医師は診断，治療以外はあまり関与 しないシステムのようである。昨年度で 7,500 名登録し たが予後調查同意は 3,400 名のみであり，単なる追跡と いえども同意取得の難しさを表している，今後は同意を 得なくてもよい方法を検討するという。調査結果では虚 血性脳卒中が $73.4 \%$ で 2 時間以内入院がその $24 \%$ であ り，4,107 例中 t-PA 治療は $9 \%$ に行われたという。また 
2 時間以内入院例では $17 \%$ とかなりの頻度で実施され たとしている.さらに最近では電子カルテ対応の院内版 データベースも開発しているとの学会報告もあった。

米国ではかつて NIH で行っていた脳卒中データバン クは中止となったが, 最近 t-PA 治療の調查を目的とし たデータベースが構築されている ${ }^{5)}$. WAVE1 として数州 規模で web site 登録方式により 3 力月間に 6,000 例を登 録し，虚血性脳卒中が $80 \%$ を占め，3 時間以内入院が $22 \%, \mathrm{t}-\mathrm{PA}$ 治療実施例が $4.6 \%$ (60 分以内入院では $58.6 \%)$ であったと報告している，その後の WAVE 2 で は, 159 病院で 21,259 例の登録を行い解析しているとの 報告があった。登録病院の例として 954 床の Duke 大学 病院では，年間 705 名の脳卒中患者が登録されたとして いる.

脳卒中データベースの条件として，1）目標を明示， 2 ）病院の仕事中に入力可能，3）発症率をみる疫学研 究は不可, 4) 単純である (複雑かつ学術研究目的は不 可)，5）急性期脳卒中のモニタリングを目的とする,

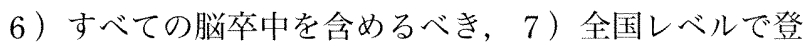
録するべきことを, 同じ 29th International Stroke Conferenceの脳卒中データバンクシンポジウムで Broderick JPが述べていたが, まさに同感であった。

\section{地域脳卒中診療拠点病院構想}

厚生労㗢省は，癌に関してはすでに 2001 年 8 月に一 般病院を中心とする地域癌診療拠点病院の指定要件を発 表し，すでに全国で承認を行っている，その条件は，診 療体制として専門的医療体制，緩和ケア，病䛦連携が実 施されていること，尃門看護師，MSW，諩療録管理士な ぞがそろっており，医療施設としては集中治療室，放射 線治療施設などがあり，医療機器としては高度な医療機 器が整備されていることを挙げている。また，院内癌登 録システム（全国共通データベースに登録）の整備を挙 げている（現在，すべての癌の共通データベースが開発 中であるが，まだ完成には至っていないようである)。研 修体制としては，地域および院内医療従事者の研修を実 施すること，情報提供体制としてホームページへの地域 癌骖療情報公開, 医療機関からの相談に対応し情報提供 を行うこと, 癌情報の収集抢よび提供 (5 年生存率など) を行うことなどを条件としている。

同様な構想は，日本に抢ける死因の第 3 位でから発生 頻度，有病率において，三大成人病の中でトップの脳卒 中でも検討されるべきものと思われる。 その理由として, 近い将来に超急性期脳梗塞に対する $\mathrm{t}-\mathrm{PA} の$ 保険適応承
認の可能性があり，脳梗塞の専門的治療（血栓溶解療法 など）が普及する可能性があり，その場合には脳卒中専 門医による迅速な診断，治燎が必要となることが挙げら れる。このためには脳卒中拠点診療病院で急性期治療を 行う体制，すなうち，1時間以内に搬送し，血栓溶解療 法が実施できる救急システムなどを整備する必要があ る。地域癌診療拠点病院の指定要件に沿って脳卒中にお ける条件を考えてみると，誟療体制として脳卒中專門医 による䀢療体制，病診連携がなされていること，専門看 護師，MSW，診療録管理士などがそろっており，医療施 設として 24 時間救急対応で集中治療室，脳卒中ケアユ ニット（またはチーム）があり，䀢療機器としては CT (24 時間稼働), MRI, SPECT, 血管撮影装置などが整備 されていること，院内脳卒中登録システム（脳卒中標準 データベース) が稼㗢し（可能なら JSSRS 脳卒中データ バンクヘ登録)，情報提供体制としてホームページへの脳 卒中殓療成績の公開，地域脳卒中診療情報公開，医療機 関からの相談に対応し情報提供を行うこと，研修体制と して地域および院内医療従事者の研修を実施することな どが挙げられる。ただし，地域癌診療拠点病院と異なる のは，脳卒中は癌と異なり一刻を争う救急疾患，すなわ ち brain attack であることである。したがって，地域癌 診燎拠点病院のように二次医療圈に 1 力所といった指 定ではなく，条件を満たす病院をできるだけ多く指定す る必要がある。予算措置などなくても，この指定により 脳卒中救急病院が国民に明示されることによって地域の 救急搬送システムの効率化が図られ，病診連携が促進さ れることにつながると思われる。

\section{おわりに}

脳卒中データバンクによる解析で脳卒中の現状が明ら かになりつつあるが，t-PA が認可された時には，open prospective study として急性期脳梗塞の連続例の登録を 行う必要がある。すでに米国，ドイッ，カナダではこの 上うな目的でデータバンクをスタートさせている。わが 国でもすでに標準になりつつある脳卒中データバンクを さらに普及させ, $\mathrm{t}-\mathrm{PA}$ 治療を実施する施設では必須化し て大規模なデー夕蓄積を行っていく必要がある。これに より，より上い適応，投与法などを明らかにして，本当 の意味での日本人のための脳卒中ガイドラインを作って いくことが重要である.

\section{文 献}

1）小林祥泰 (主任研究者)：脳卒中急性期患者データベース 
構築に関する研究. 2001 年度厚生省科学研究費補助金統 括研究報告書, pp. 5-169，2001.

2）小林祥泰：日本人に打りる脳卒中リスク一脳卒中デー夕 バンクより. Hypertension Frontier 2004, in press.

3）山口武典：脳梗塞急性期医療の実態に関する研究。2000 年度厚生省科学研究費補助金統括, 2001 .

4）小林祥泰：脳卒中急性期治㙩へのアプローチ。最新医学 58:811-818, 2003

5) Schwamm LH: Paul coverdell pilot prototypes-wave Imoving from pilot data to ongoing process. 29th International Stroke Conference, 2004.

6）小林祥泰：日本における brain attack の現状と将来の予 測。臨床神経 41：1049-1051，2001.

7) The National Institute of Neurological Disorders and Stroke t-PA Stroke Study Group: Tissue plasminogen activator for acute ischemic stroke. $N$ Engl J Med 333 : 1581-1587, 1995
8）小林祥泰，寺畸修司，橋本洋一郎，井上 勲，中川原讓 二, 山田 猛, 鈴木明文, 山㱦正博, 山本康正, 永山正 雄, 鄭 秀明, 岡田 靖, 柏原健一, 北川一夫, 棚橋紀 夫, 野村栄一, 高木 誠, 平田幸一, 鈴木倫保：超急性 期入院虚血性脳血管障害の通常治療による 3 力月日の転 㷌一脳卒中急性期患者データベースによる前向き検討。 脳卒中 26:323-330, 2004 .

9）與 麗華, 高橋一夫, 小林祥泰, 田 国萍, 朵 利春, 松井龍吉, 山口修平: 脳卒中急性期患者データベースを もちいた日本と中国（瀋陽术）に抢ける脳梗塞の比較。 臨床神経 44:335-341，2004.

10) Schenkel J, Weimar C, Knoll T, Haberl RL, Busse $O$, Hamann GF, Koennecke HC, Diener HC: R1--systemic thrombolysis in German stroke units--the experience from the German Stroke data bank. J Neurol 250:320324, 2003.

要

旨

脳卒中標準データベースの有用性

小林 祥泰

Japan Standard Stroke Registry Study (JSSRS) group では，日本人のための EBM を確立するた めの infrastructure として, 国際標準指標を用いた全国しベルで継続性のある脳卒中急性期患者データ バンクを構築しつつある. 虚血性脳卒中では保険適応はないが, 超急性期血栓溶解療法が行われた例 についての解析を行い，その有用性を示唆する結果を得ている，脳出血でも，選択された例において は手術の有効性が示唆された. 本システムは急性期脳卒中を扱う中核病院の臨床データベースとして も継続的に機能するものであり，各施設における脳卒中診療の正確な把握，全国標準の集計が容易と なり，医療情報開示，インフォームド・コンセントなどに必要な資料作成にも大きな威力を発揮する。

脳外誌 $14: 3-9,2005$

\section{脸神経外科ジャーナルー匀号予告}

第 14 巻 第 2 号 2005 年 2 月

\section{総 説}

神経血管隇圧術のための外科解剖 ·浜の町病院 松島 俊夫，他 椎骨動脈圧迫による顔面痤攣一病因論と手術法 帝京大学 藤巻 高光, 他

顔面疗攣の再手術一症状再発の予防と対策 城山病院 近 藤 明㥁 アジアの脳神経外科一過去 10 年の歩みと末来展望 藤田保健衛生大学 神 野 哲 夫

\section{特別寄稿}

History of Neurosurgery in India Seth G.S. Medical College Atul H. Goel，他 Neurosurgery in the Arab World : Current State and Future Prospects Jordan University of Science and Technology Mohammad A. Jamous

原 著

再発および未治癒三叉神経痛に対する外科治療 北野病院 石川 正恒, 他

編集の都合上内容が若干異なる場合がありますのでご了承ください。 